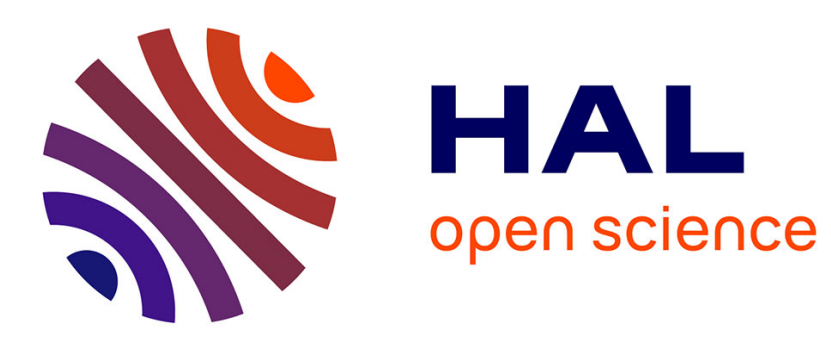

\title{
Dynamic headspace analysis. Modification of a commercial system for off-line collection
}

\author{
Pierre Frasse, Daniel Richard-Molard
}

\section{To cite this version:}

Pierre Frasse, Daniel Richard-Molard. Dynamic headspace analysis. Modification of a commercial system for off-line collection. HRC and CC. Journal of High Resolution Chromatography and Chromatography Communications, 1989, 12 (9), pp.631-632. hal-02720305

\section{HAL Id: hal-02720305 \\ https://hal.inrae.fr/hal-02720305}

Submitted on 1 Jun 2020

HAL is a multi-disciplinary open access archive for the deposit and dissemination of scientific research documents, whether they are published or not. The documents may come from teaching and research institutions in France or abroad, or from public or private research centers.
L'archive ouverte pluridisciplinaire HAL, est destinée au dépôt et à la diffusion de documents scientifiques de niveau recherche, publiés ou non, émanant des établissements d'enseignement et de recherche français ou étrangers, des laboratoires publics ou privés. 
with samples wherein the content of the sulfur compounds was unknown (sample range from $100 \mu \mathrm{l}$ to $1000 \mu \mathrm{l}, n=7$ ). They indicate a constant conversion factor for each of the tested sulfur compounds. A stoichiometric conversion has been reported $[11,12]$ for this type of compounds in the reductive pyrolysis mode at about $800^{\circ} \mathrm{C}$. This could imply that the conversion in the pyrolysis was quantitative in this study, which consequently would allow the quantification of the response data for PID II into the absolute amount of the original sulfur compounds. A further investigation of the GC/PID sulfur-specific operation will involve this aspect and the analysis of air samples containing organic halogen compounds.

\section{References}

[1] I. Krull, M. Swartz, and J.N. Driscoll in "Advances in Chromatography", Vol. 24. J.C. Giddings et al. (eds) Marcel Dekker. New York (1984) 247.

(2) R.F. Earp, and R.D. Cox in "Identification and Analysıs of Organic Poilutants in Air", L.H. Keith (ed), Butterworth. Woburn, USA (1984) 159
[3] S.O. Farwell, and C.J. Barinaga, J. Chromatogr. Sci. 24 (1986) 483.

[4] M. Dressier, "Selective Gas Chromatographic Detectors", Elsevier Amsterdam (1986) Chap. 6

[5] W. Bretschneider, and P. Werkhoff, HRC \& CC 11 (1988) 543

[6] C.J. Barinage, and S.O. Farwell, HRC \& CC 10 (1987) 538

[7] M. Dressler, "Selective Gas Chromatographic Detectors", Elsevier Amsterdam (1986) Chap. 9

[8] F. Wodtcke, Chem. Ing. Tech. 53 (1981) 731.

[9] M.L. Langhorst, Am. Ind. Hyg. Assoc. J. 44 (1983) 592.

[10] J.N. Driscoll, Ind. Hygiene News 3 (1980)No. 1

[11] L.D. Wallace, D.W. Kohlenberger, R.J. Joyce, R.T. Moore, M.E. Riddle, and J.A. MCNulty Anal. Chem. 42 (1970) 387.

[12] J. Lamgmaier, F. Opekar, and V. Pacáková, Talanta 34 (1987) 453.

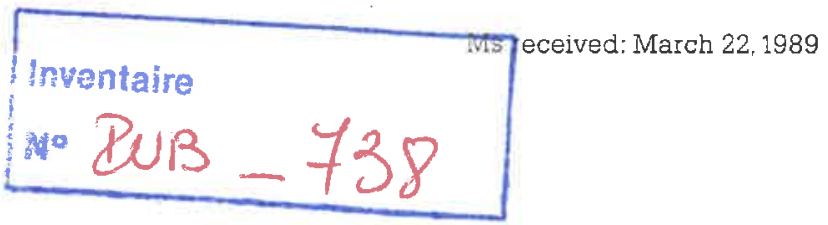

\title{
Dynamic Headspace Analysis- Modification of a Commercial System for Off-Line Collection
}

\author{
P. Frasse* and D. Richard-Molard \\ Institut National de la Recherche Agronomique, Laboratoire de Microbiologie et Technologie Céréalière, BP 527, \\ 44026 Nantes Cedex 03, France
}

\section{Key Words:}

GC

Dynamic headspace analysis

Commercial system

Sampling

\section{Introduction}

The headspace technique is widely employed in numerous fields such as analysis of water and air pollutants. biological fluids, and food products [1-2]. 3oth static and dynamic methods are used, but in case of extremely low concencration levels where large sample volumes are necessary, the dynamic approach is more convenient because of the possible enhancement of the components. Actually, several headspace analysis (HSA) systems are commercially available but as shown recently by Schaeffer [3], none of them is ideal for all appications. The initial conception of a given system contributes argely to its functionaiity, and the possibility of choice and modification of some of ats constituent parts is necessary for good adaptation and optimization of the technique for a particular application. In this connection. the present paper describes a modification of the trap support of a commercial system for dynamic HSA which allows its much more flexible use, particularly for off-line collection, and eliminate some of the disadvantages arising because the trap cannot be moved in the original version.

\section{Experimental}

The original system (DCI ${ }^{1}$-Delsi Instrument, France) consisted of a compact dynamic HSA device which could be coupled directly to a gas chromatograph, and possessed two independent gas circuits for collection and desorption of the analyzed substances. Concentration was carried out with a stainless steel tube $(6 \times 1 / 8 /$ in. $)$ tilled with about $200 \mathrm{mg}$ of Tenax GC (60-80 mesh), which could be cooled by liquid nitrogen (collection) and heated by the Joule effect (desorption $2000 \% \mathrm{~min}$ ) in a range of abcut -180 to $+340^{\circ} \mathrm{C}$. All the differentsections (six-way valves, transfer lines, etc.) are temperature controiled and could be programmed (except for the desorption time of the tube).

Because the trap could not be removed there was no possibility of replacing the adsorbent by others, such as activated carbon, graphitized black carbon, other porous polymers (Tenax TA, Porapak, etc.) or Amberlite resins, which have different proper-

Desorption-Concentration-Introduction 
ties regarding, e.g. surface area, temperature limit, and which are more convenient for some applications [4-5]. In addition, no blackfush could be performed before the desorption of the trap so that elimination of water or volatile solvents was not possible prior to injection onto the chromatograhic column. This makes it particularly unsuitable for the study of high moisture content products [6]. Lastly, heating of the trap in the original configuration was only possible during the desorption stage, which was limited to about $1.5 \mathrm{~min}$. Thus thorough clean-up by off-line baking was impossible. In view of these disadvantages, we decided to modify the system as far as possible without loss of functionality, ie. by preserving the geometrical arrangement of the original version in such a way that control and regulation capacities were maintained. A "sheath-like system" was adopted for tube manipulation (see Figure 1), with articulation of the support of the adsorbent tube such that the latter could be removed and replaced easily and quickly

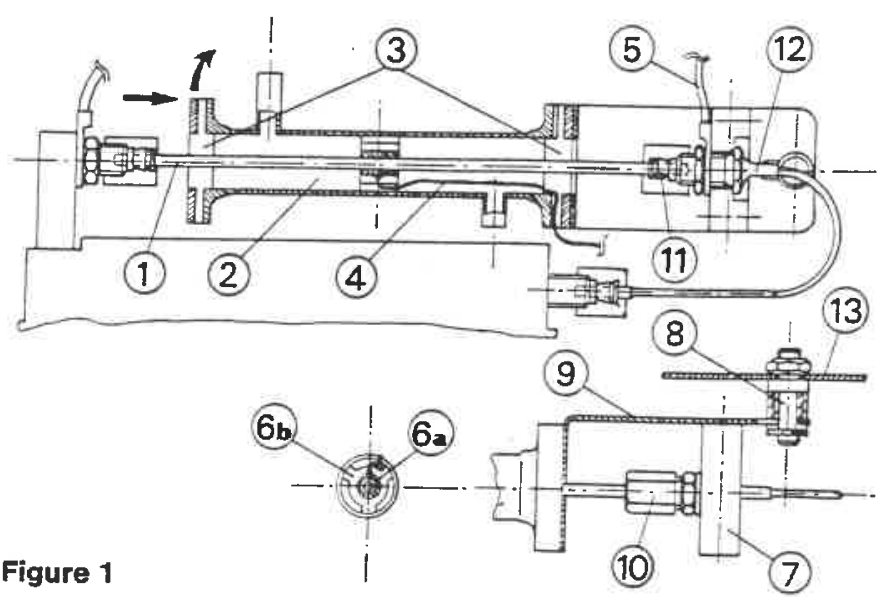

Collecting section after modification: 1 = trap tube; 2 = cooling chamber; $3=$ PTFE join; 4 = thermocouple; $5=$ electrical connections; $6 a=$ brass ring; $6 b=$ PTFE plug; $7=$ PTFE part; $8=$ rotation axis; $9=$ stainless steel angle; $10=$ Swagelock fitting nut; $11=$ Vespel ferrule; $12=$ zero dead vo. lume fitting (S.S. $\left.1 / 8^{\prime \prime} \times 1 / 16^{n}\right) ; 13=$ system support.

At one end of the trap tube (1), the soldered electrical connection used for heating during the thermal desorption stage was replaced by a screw connection (5) resembling that at the other end. The thermocouple (4) for measurement and control of the temperature of the trap during desorption was welded in a brass ring (6a) closely fitted on the tube and maintained in the middle of the cooling chamber (2) by a PTFE plug (6b). An axis of rota- tion (8) allowed articulation of the new stainless steel angle (9) connected to the trap support. PTFE parts $(7,8)$ were necessary for thermal and electrical insulation.

For the sake of simplicity, the external dimensions of the trap tube (1) were maintained and its connection to the desorption lines made by use of Swagelock connectors (10) (with no additional dead volume) and graphitized vespel ferrules (11). Setting and removing of the tube was achieved by disconnecting the Swagelock fitting nuts, pushing and pivoting the body of the cooling chamber (arrows). This operation took less than $30 \mathrm{~s}$

\section{Results}

The modified DCI system has been run regularly five to eight times a day for more than six months without any trouble. The only limitations found were: periodic replacement of vespel ferrule and restriction of the desorption temperature to $270^{\circ} \mathrm{C}$ (higher temperatures would damage PTFE flasks). This last point could certainly be resolved by use of a more heat resistant material if necessary. The movability of the trap makes it more convenient for off-line sampling and adaptation of the adsorbent to a given application. Soit becomes possible to regenerate several adsorbent tubes for subsequent analyses. The "development step" (backflushing) allows the elimination of possible remaining "heavy" components after injection. It could also prevent the oxidation of the adsorbent which can be easily controlled and replaced if degradation occurs (thermal decomposition). Studies of breakthrough volume by use of identical traps in serial is also possible. Even more important, it becomes possible to study the design of the trap tube itself (internal diameter, kind of material) for its good adaptation to HRGC. The function of the original device is maintained.

\section{References}

[1] G. Charalambous (Eds). "Analysis of food and beverage, Headspace Techniques", Academic Press, New York (1978).

(2) B. V. Ioffe and A. G. Vitenberg, "Headspace Analysis and Related Methods in Gas Chromatography", Wiley, New York (1984).

[3] H. J. Schaeffer, HRC, 12 (1989) 69.

[4] B. Barnes, L. Marialaw, and A. MacLeodt, Analyst. 106 (1981) 412.

[5] J. Schaefer in "Flavor 81", P. Schreier (Ed), de Gruyter, New York (1981).

[6] W. G. Jennings, R. Wohleb, and M. J. Lewis, J. Food. Sci 37 (1972) 69 Ms received: April 21, 1989 